\title{
ISOLASI DAN KARAKTERISASI SENYAWA ANTIBAKTERI DARI BULU BABI
}

\section{Isolation and Characterization of Antibacterial Compounds from Sea Urchin}

\author{
Febrina Olivia Akerina ${ }^{\star}$, Tati Nurhayati, Ruddy Suwandy \\ Departemen Teknologi Hasil Perairan Fakultas Perikanan dan Ilmu Kelautan Institut Pertanian Bogor. \\ Jalan Agatis Lingkar Akademik, Kampus IPB Darmaga, Bogor 16680. \\ Telepon : 0251-622915 Faks. : 0251-8622916 \\ *Korespondensi: feraakerina@rocketmail.com \\ Diterima 20 Februari 2015/Disetujui 20 April 2015
}

\begin{abstract}
Abstrak
Bulu babi merupakan biota perairan yang memiliki nilai gizi tinggi. Senyawa bioaktif yang dihasilkan oleh bulu babi memiliki potensi untuk dimanfaatkan sebagai senyawa antibakteri alami. Penelitian ini bertujuan untuk mendapatkan ekstrak bulu babi menggunakan metode maserasi, menentukan aktivitas antibakteri menggunakan metode difusi sumur; menentukan komponen gizi berdasarkan AOAC, komponen bioaktif menggunakan metode fitokimia dan toksisitas ekstrak bulu babi Diedema setosum menggunakan brine shrimp lethality test (BSLT). Bulu babi diperoleh dari Pulau Pramuka Kepulauan Seribu sebanyak 200 ekor. Ekstrak gonad bulu babi memiliki aktivitas antibakteri tertinggi dengan zona hambat $(1,83 \pm 0,74)$ $\mathrm{mm}$ terhadap bakteri Escherichia coli dan 1,5 mm terhadap bakteri Staphylococcus aureus. Komposisi kimia gonad bulu babi secara berurutan adalah kadar air (64,97 $\pm 0,08 \%)$; kadar abu $(2,72 \pm 0,13 \%)$; kadar lemak $(19,73 \pm 0,04 \%)$; kadar protein (12,26 $\pm 0,3 \%)$; dan kadar karbohidrat $(0,33 \pm 0,17 \%)$. Komponen bioaktif yang terdeteksi pada ekstrak n-heksana, etil asetat, dan metanol gonad bulu babi adalah golongan steroid, triterpenoid, dan saponin. Nilai $\mathrm{LC}_{50}$ ekstrak gonad bulu babi dari masing-masing pelarut berturut-turut ekstrak n-heksana 471,861 ppm, etil asetat 563,226 ppm, dan metanol 577,531 ppm. Aktivitas antibakteri ekstrak gonad bulu babi terbaik diperoleh dari ekstrak etil asetat pada konsentrasi $2 \mathrm{mg}$ dengan diameter zona hambat $2,71 \mathrm{~mm}$ terhadap bakteri S. aureus dan 4,13 terhadap bakteri E. coli.
\end{abstract}

Kata Kunci : Antibakteri, bulu babi, D. setosum, senyawa bioaktif

\section{Abstract}

Sea urchin is highly valued seafood. Its bioactive compound also has a potential as natural antibacterial agent. The aim of this research was to screen the antibacterial activity using cup-plate method, toxicity potential using brine shrimp lethality test (BSLT) method, bioactive compound using phytochemical method, and proximate composition by AOAC. This research was devided into two phases, the preliminary research was to determine the best body part of sea urchin showing antibacterial activity. Sea urchins were collected from Pramuka Island and extracted by meseration method. For the preliminary research, gonad extract showed the high antibacterial activity against $E$. coli and $S$. aureus at $1.83 \pm 0.74 \mathrm{~mm}$ and $1.5 \mathrm{~mm}$, respectively. The main research includes the determination of proximate composition, toxicity, bioactive compound, and antibacterial activity from the best body part of sea urchin. The proximate composition from gonad of sea urchin showed that water content $64.97 \pm 0.08 \%$; ash $2.72 \pm 0.13 \%$; lipid $19.73 \pm 0.04 \%$; protein $12.26 \pm 0.3 \%$, and $0.33 \pm 0.17 \%$, respectively. The detected bioactive compounds from the three different solvents of gonads extracts were steroid, triterpenoid and saponin. The result of lethal toxicity $\left(\mathrm{LC}_{50}\right)$ from the three gonads extract was $471.861 \mathrm{ppm}$ (n-hexane), $563.226 \mathrm{ppm}$ (ethyl acetate) and 577.531 ppm (methanolic), respectively. Gonads ethyl acetate extracts showed the highest antibacterial activity than $\mathrm{n}$-hexane and methanolic extract, its inhibition zone was $2.71 \mathrm{~mm}$ against $S$. aureus and 4.13 against E. coli.

Keyword : Antibacteria, bioactive compound, D. setosum, sea urchin 


\section{PENDAHULUAN}

Bulu babi merupakan salah satu jenis biota perairan yang berasal dari filum echinodermata. Penyebaran bulu babi terlihat hampir di seluruh zona perairan. Suwignyo et al. (2005) menyatakan bahwa ada 950 spesies bulu babi yang tersebar di seluruh dunia. Penyebaran bulu babi di perairan Indonesia, Malaysia, Filipina, dan wilayah Australia Utara sekitar 316 jenis, sedangkan di perairan Indonesia sendiri sekitar 84 jenis yang berasal dari 48 marga dan 21 suku (Aziz 1987).

Diadema setosum merupakan salah satu jenis bulu babi yang penyebarannya di seluruh zona terumbu karang antara lain pada zona pasir, zona pertumbuhan alga, zona lamun sampai daerah tubir (Zakaria 2013). Populasi spesies lebih banyak ditemukan pada daerah karang yang kondisinya telah rusak. Spesies ini hidupnya mengelompok dengan tujuan untuk mempertahankan diri dari ancaman musuh. Satu kelompok terdiri dari 20-40 individu, dan bisa mencapai ratusan individu dimana kelompok tersebut dapat berpindah-pindah. Bulu babi secara umum merupakan hewan nokturnal yang aktif pada malam hari, sepanjang siang mereka bersembunyi di celah-celah karang dan keluar pada malam hari untuk mencari makan. Secara umum bulu babi memakan alga coklat, alga hijau dan lamun sebagai makanan utamanya sedangkan D. setosum, karena hidupnya di bawah batas surut terendah maka sumber makanannya berasal dari berbagai jenis alga serta partikel organik/detritus (Ratna 2002).

Bulu babi memiliki cangkang yang keras dan bagian dalamnya bersisi lima simetris. Bulu babi jenis tertentu memiliki cangkang yang dilapisi oleh pigmen cairan hitam yang stabil. Selain memiliki cangkang yang keras, 95\% bagian tubuh bulu babi didominasi oleh duriduri yang sangat rapuh dan sedikit beracun. Duri ini digunakan untuk bergerak, melindungi diri, serta mencapit makanan, dan untuk jenis-jenis tertentu mengandung racun. Abubakar et al. (2012) menyatakan bahwa toksin yang dihasilkan oleh organisme salah satunya bulu babi dapat dimanfaatkan dalam bidang pengobatan yang berpotensi untuk dimanfaatkan sebagai antibiotik tipe baru untuk dikembangkan dalam bidang farmasi karena mengandung senyawa bioaktif.

Hewan-hewan laut tidak terlindungi dari bakteri-bakteri yang toleran terhadap konsentrasi tinggi, jamur, dan virus, yang mungkin saja bersifat patogen terhadap organisme tersebut. Pertahanan dari suatu organisme tergantung dari efisiensi senyawa antimikroba yang dihasilkan untuk dapat melindungi dirinya terhadap infeksi mikroba tersebut (Abubakar et al. 2012). Li et al. (2010) melaporkan bahwa $43 \%$ aktivitas antimikroba berasal dari 83 spesies echinodermata yang tidak diidentifikasi yang diperoleh dari pantai barat Baja California dan Teluk California sebesar 58\% dari 36 spesies yang tidak diidentifikasi dari Laut Karibia juga menunjukkan aktivitas antimikroba. Bryana et al. (1997) menyatakan bahwa di Teluk Meksiko, 80\% dari 22 spesies echinodermata menunjukkan aktivitas antimikroba. Penelitian lainnya yang dilaporkan oleh Haug et al. (2002) menunjukkan bahwa aktivitas antibakteri ditemukan pada bagian tubuh yang berbeda dari green sea urchin dengan menggunakan bakteri uji Vibrio anguillarum serotipe $\mathrm{O}_{2}$ (FT 1801), Escherichia coli (ATCC 15922) dan Staphylococcus aureus (ATCC 9144) dan Corynebacterium glutamicum (ATCC 13032). Hasil ini menunjukkan bahwa filum echinodermata salah satunya bulu babi memiliki potensi sebagai antimikroba alami (Uma dan Parvathavarthini 2010).

Aprilia et al. (2012) menyatakan duri dan cangkang bulu babi memiliki potensi sebagai antimikroba karena memiliki kandungan senyawa bioaktif yang bersifat toksik, senyawa tersebut antara lain histamin, serotoin, glikosida, steroid, bahan cholinergic, dan brandykinin-like substances (Dahl et al. 2010). Abubakar et al. (2012) menyatakan bahwa berbagai faktor antimikroba yang berasal dari echinodermata yaitu steroidal glikosida (Andersson et al. 1989), sterol polihidroksilat (Iorizzi et al. 1995), lisosom (Canicatti dan Roch, 1989; Stabili dan Pagliara, 1994), complementlike substance (Leonard et al. 1990) dan peptida antimikroba (Beauregard et al. 2001). 
Penelitian mengenai isolasi dan karakterisasi komponen bioaktif dari bulu babi di Indonesia belum banyak dilakukan, penelitian lebih banyak diarahkan pada uji toksisitas, asam lemak, asam amino, logam berat, dan sebagainya. Potensi bulu babi sebagai antibakteri perlu dikembangkan karena dapat dimanfaatkan sebagai bahan obat dalam bidang farmasi. Penelitian ini bertujuan untuk mendapatkan ekstrak bulu babi menggunakan metode maserasi, menentukan aktivitas antibakteri menggunakan metode difusi sumur; menentukan komponen gizi berdasarkan AOAC, komponen bioaktif menggunakan metode fitokimia dan toksisitas ekstrak bulu babi Diedema setosum menggunakan brine shrimp lethality test (BSLT).

\section{BAHAN DAN METODE \\ Bahan dan Alat}

Bahan yang digunakan dalam penelitian ini adalah bulu babi jenis Diadema setosum yang diambil dari Pulau Pramuka, Kepulauan Seribu, Jakarta. Pelarut yang digunakan untuk ekstraksi adalah metanol (Merck), etil asetat (Merck), dan n-heksana (Merck). Bahan lain yang digunakan untuk analisis adalah bakteri Escherichia coli (ATCC 8739) dari IPBCC, Staphylococcus aureus (ATCC 6538) dari LIPI Cibinong, Nutrient Agar (NA), Nutrient Broth (NB), Mueller Hinton Agar (MHA), akuades, larva Artemia salina.

Alat-alat yang digunakan dalam penelitian ini antara lain, orbital shaker (WideShake SHO-1D), vacum rotary evaporator (Eyela OSB-2110), autoklaf (Yamato SM 52), spektrofotometer (UV VIS RS 2500), inkubator (Yamato IS900), laminar, oven sterilisasi (Yamato SH62), oven pengering (EHRET), vial BSLT.

\section{Prosedur Penelitian}

Penelitian ini dibagi menjadi dua bagian yakni penelitian pendahuluan dan penelitian utama. Penelitian pendahuluan terdiri dari proses ekstraksi dan pengujian aktivitas antibakteri bulu babi. Penelitian utama meliputi analisis proksimat, yakni kadar air, kadar abu, kadar protein, kadar lemak dan kadar karbohidrat (by difference); analisis fitokimia yakni steroid-terpenoid, flavonoid, alkaloid, saponin, fenol hidrokuinon, dan ninhidrin; analisis brine shrimp lethality test (BSLT); analisis aktivitas antibakteri metode difusi sumur.

\section{Ekstraksi}

Ekstraksi dilakukan dengan cara sebanyak $50 \mathrm{~g}$ sampel direndam dalam pelarut n-heksana, etil asetat dan metanol dengan perbandingan $1: 3$ selama 3 x 24 jam. Ekstrak disaring menggunakan kertas saring kemudian dievaporasi dengan vacum rotary evaporator pada suhu $37-40^{\circ} \mathrm{C}$, selanjutnya ekstrak disimpan pada suhu chiling $\left(0-4^{\circ} \mathrm{C}\right)$ sebelum dianalisis.

\section{Analisis aktivitas antibakteri (Moorthy et al. 2007)}

Pengujian aktivitas antibakteri terhadap bakteri uji menggunakan metode difusi sumur. Sumur dengan kedalaman $\pm 3 \mathrm{~mm}$ dibuat pada MHA yang telah dicampurkan dengan $20 \mu \mathrm{L}$ inokulum bakteri uji dengan menggunakan pipet tetes steril. Ekstrak dengan konsentrasi $0,5 \mathrm{mg}, 1 \mathrm{mg}$, dan $2 \mathrm{mg}$ ditetes ke dalam sumur sebanyak $20 \mu \mathrm{L}$. Perlakuan kontrol positif menggunakan antibiotik kloramfenikol, dan kontrol negatif menggunakan pelarut metanol, etil asetat, dan n-heksana. Media diinkubasi pada suhu $37^{\circ} \mathrm{C}$ selama 24 jam, pengamatan terhadap aktivitas antibakteri dilakukan tiap dua jam untuk menentukkan sifat ekstrak terhadap bakteri uji. Aktivitas antibakteri ditandai dengan terbentuknya zona bening di sekitar sumur dan diukur menggunakan penggaris.

\section{Analisis Toksisitas (BSLT) (Mayer et al. 1982)}

Pengujian dilakukan dengan cara telur Artemia salina diretaskan di dalam air laut selama 24-48 jam, selanjutnya larva siap digunakan sebagai hewan uji. A. salina dimasukkan dalam vial (sumur) yang telah berisi ekstrak bulu babi terbaik dengan konsentrasi masing-masing 0, 50, 100, 200, 
500, dan 1000 ppm dengan 3 kali ulangan. Vial tersebut kemudian diinkubasi selama 24 jam. Pengamatan dilakukan dengan melihat jumlah A. salina yang mati pada masing-masing vial (sumur). Penentuan $\mathrm{LC}_{50}$ dilakukan dengan analisis probit dengan selang kepercayaan 95\% pada program SPSS 22.

\section{HASIL DAN PEMBAHASAN}

\section{Morfometrik dan Rendemen Bulu Babi}

Diadema setosum (Gambar 1) yang digunakan dalam penelitian ini diambil dari Pulau Pramuka, Kepulauan Seribu. Pengukuran diameter dan berat bulu babi dilakukan terhadap 30 ekor bulu babi, ratarata diameter bulu berkisar antara 5,8-7,0 $\mathrm{cm}$, dengan berat berkisar antara 57-63 g. Hubungan pertumbuhan diameter dengan pertambahan berat bulu babi adalah isometrik, sedangkan pertambahan berat cangkang dan berat total tidak secepat pertambahan tinggi cangkang (Tuwo 1995). Dincer dan Cakli (2007) menyatakan bahwa meningkatnya berat gonad (telur) seiring dengan meningkatnya berat total bulu babi, tapi hubungan ini terjadi hanya pada saat proses bertelur (spawning) dari bulu babi tersebut.

Rendemen merupakan persentase perbandingan antara berat bagian bahan yang digunakan dengan berat total bahan. Berat total bulu babi 30 ekor adalah $610 \mathrm{~g}$ dengan presentase masing-masing yakni duri $17,37 \%$, cangkang $46,72 \%$, gonad $8,03 \%$, dan bagian lainnya 16,88\%. Cangkang dan duri merupakan bagian dengan persentase rendemen tertinggi dibandingkan gonad dan bagian lain. Bulu babi merupakan hewan laut yang sebagian besar tubuhnya dilapisi dengan cangkang dan duri. Cangkang bulu babi (endoskleton) merupakan kerangka kapur dan tersusun dari kalsium karbonat. Penyusun utama duri bulu babi adalah kalsium karbonat dan magnesium. Ukuran duri bulu babi berbeda-beda tergantung jenis. Duri D. setosum tajam dan lebih mudah rapuh. Selain digunakan sebagai pertahanan terhadap musuh, duri bulu babi juga digunakan untuk berpindah-pindah (Vimono 2007).

\section{Ekstraksi Bulu Babi}

Proses ekstraksi dilakukan untuk mendapatkan senyawa bioaktif dari bagian tertentu suatu bahan dan proses ini sangat tergantung pada kadar air yang terkandung dalam bahan dan tekstur bahan yang akan diekstraksi serta jenis zat yang akan diisolasi (Harborne 1984). Alkohol merupakan pelarut yang baik digunakan untuk ekstraksi pendahuluan karena dapat mengekstraksi habis komponen aktif. Pelarut metanol dapat mengekstrak komponen alkaloid, komponen fenolik, karotenoid, tanin, gula, asam amino, dan glikosida. Ekstraksi bulu babi dilakukan terhadap tiga bagian berbeda yaitu cangkang, duri, dan gonad menggunakan pelarut metanol. Rendemen ekstrak masing-masing bagian bulu babi dapat dilihat pada Tabel 1 .

Bagian bulu babi yang menghasilkan rendemen tertinggi adalah gonad yakni $7,10 \%$ dan terendah adalah duri yakni $0,94 \%$. Rendemen gonad bulu babi yang tinggi mengindikasikan banyak komponen bioaktif yang mampu diekstrak oleh pelarut metanol.

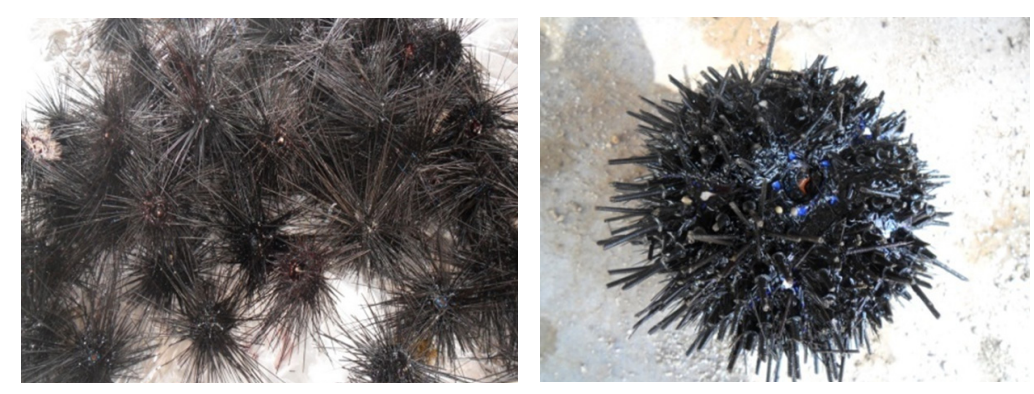

Gambar 1 Diadema setosum 
Tabel 1 Hasil analisis ekstrak bulu babi

\begin{tabular}{|c|c|c|c|}
\hline \multirow{2}{*}{ Bagian bulu babi } & \multirow{2}{*}{$\begin{array}{l}\text { Rendemen ekstrak } \\
\text { metanol (\%) }\end{array}$} & \multicolumn{2}{|c|}{ Antivitas antibakteri $(\mathrm{mm})$} \\
\hline & & S. aureus & E. coli \\
\hline Cangkang & 1,64 & $1,25 \pm 0,25$ & $1,63 \pm 0,63$ \\
\hline Duri & 0,94 & - & 1,5 \\
\hline Gonad & 7,10 & 1,5 & $1,83 \pm 0,74$ \\
\hline Bagian lain & - & - & - \\
\hline
\end{tabular}

Keterangan: Konsentrasi ekstrak yang digunakan 10000 ppm

Kadar air yang tinggi juga diduga merupakan faktor lain yang mempengaruhi tingginya rendemen gonad bulu babi, karena gonad bulu babi tidak dikeringkan sebelum diekstraksi, berbeda dengan cangkang dan duri. Pelarut metanol merupakan pelarut polar yang mampu mengekstrak komponen dalam bahan termasuk air (Rahayu 1999).

\section{Aktivitas Antibakteri Bulu Babi}

Adanya aktivitas antibakteri terhadap bakteri uji ditunjukkan dengan terbentuknya zona hambat. Zona hambat yang ditampilkan telah dikurangi diameter sumur sebesar $6 \mathrm{~mm}$ (Tabel 1). Zona hambat tertinggi ditunjukkan pada ekstrak gonad bulu babi yaitu, 1,83 \pm 0,74 mm terhadap E. coli dan 1,5 mm terhadap S. aureus, dibandingkan ekstrak cangkang dan duri bulu babi. Hasil ini sejalan dengan hasil yang diperoleh Abubakar et al. (2012), yakni ekstrak metanol gonad babi memiliki aktivitas antibakteritertinggi terhadap bakteri E. colidan S. aureus secara berurutan $16 \mathrm{~mm}$ dan $13 \mathrm{~mm}$. Proses pengeringan yang dilakukan terhadap cangkang dan duri diduga mempengaruhi aktivitas zona hambat yang terbentuk. Wang dan Weller (2006) menyatakan bahwa secara umum komponen bioaktif cepat mengalami kerusakan karena sifatnya yang tidak tahan panas (thermolabile).

Daya hambat ekstrak bulu babi dapat ditentukan oleh diameter zona hambatnya. Davis dan Stout (1971) menyatakan bahwa terdapat 3 kategori daerah hambatan zat aktif berdasarkan diameter zona hambatnya yakni untuk kategori lemah diameter zona hambatnya $<5 \mathrm{~mm}$, kategori sedang yakni 5-10 mm, dan kategori kuat yakni 10-20 mm. Hasil penelitian ini menunjukkan bahwa daya hambat ekstrak bulu babi termasuk kategori lemah.

\section{Komponen Kimia Gonad Bulu Babi}

Komponen gizi dalam suatu bahan sangat menentukan mutu dari bahan tersebut. Analisis proksimat bertujuan untuk mengetahui komposisi kimia gonad bulu babi yang meliputi kadar air, kadar abu, lemak, protein, abu, dan karbohidrat (by difference). Hasil analisis proksimat gonad bulu babi dapat dilihat pada Tabel 2.

Tabel 2 Komposisi kimia gonad bulu babi

\begin{tabular}{lcc}
\hline Bagian bulu babi & $\begin{array}{c}\text { Komposisi } \\
\text { kimia (\%) }\end{array}$ & $\begin{array}{c}\text { Komposisi } \\
\text { kimia }\left({ }^{*} \%\right)\end{array}$ \\
\hline Kadar air & $64,97 \pm 0,08$ & 73,4 \\
Kadar abu & $2,72 \pm 0,13$ & 2,1 \\
Kadar lemak & $19,73 \pm 0,04$ & 3,5 \\
Kadar protein & $12,26 \pm 0,34$ & 15,1 \\
Kadar karbohidrat & $0,33 \pm 0,17$ & - \\
\hline
\end{tabular}

Keterangan: ${ }^{\star Z l a t a n o s ~ e t ~ a l . ~(2009) ~}$ 
McAlister dan Moran (2012) menyatakan bulu babi memiliki tiga komponen biokimia yang penting yaitu protein, lemak, dan karbohidrat. Ketiga komponen ini merupakan penyedia energi bagi bulu babi dan penyusun struktur elemen dalam proses pembentukan dan perkembangan telur.

Kadar lemak gonad bulu babi pada penelitian ini yaitu 19,73\%. Bulu babi jenis D. setosum merupakan salah satu jenis bulu babi dengan larva planktotrofik, dimana larva memperoleh nutrisi dari organisme plankton dan detritus (Jablonsky dan Lutz 1983). Hasil yang diperoleh sejalan dengan penelitian yang dilakukan McAlister dan Moran (2012), yakni kadar lemak tertinggi ditunjukkan pada bulu babi Echinometra lucunter yang merupakan bulu babi planktotrofik 30,7\%.

Faktor yang mempengaruhi kandungan lemak dalam gonad bulu babi salah satunya adalah makanan. McAlister dan Moran (2012) menyatakan bahwa terdapat 2 jenis sumber bahan makanan bulu babi yaitu non-planktonik yang bukan berasal dari plankton tapi berasal dari kuning telur induknya dan planktotrofik yang berasal dari fitoplankton maupun zooplankton. Faktor lain yang juga mempengaruhi tingginya kadar lemak yaitu ukuran gonad, gonad bulu babi yang berukuran besar secara proporsional mengandung lemak yang lebih banyak. Kandungan lemak yang tinggi cenderung menghasilkan volume gonad yang besar, sehingga dapat dimanfaatkan sebagai cadangan energi untuk proses perkembangannya (Byrne et al. 2008)

Bulu babi diketahui merupakan salah satu hasil perikanan yang memiliki kandungan protein tinggi. Fungsi protein sangat khas yakni membangun serta memelihara sel-sel dan jaringan tubuh makhluk hidup, fungsi ini tidak dapat digantikan oleh zat gizi yang lain. Kadar protein gonad pada penelitian ini yaitu $12,2 \%$. Hasil ini berbeda dengan penelitian yang dilakukan oleh McAlister dan Moran (2012), bahwa kadar protein bulu babi planktotrofik berkisar antara 57,4-69,4\%, hal ini dikarenakan perbedaan metode yang digunakan yakni modifikasi metode Lowry sedangkan penelitian ini menggunakan metode Kjeldahl. Kamizake et al. (2003) menyatakan bahwa analisis total protein menggunakan metode spektofotometri diantaranya metode Bradford dan Lowry digunakan pada bidang analisis biokimia, fisiologi, analisis klinik dan penelitian medis lebih baik dibandingkan bidang lainnya, serta menunjukkan hasil yang lebih baik dibandingkan metode Kjeldahl, dalam penerapannya metode Kjeldahl memiliki dua masalah utama yakni membutuhkan waktu yang lama dan dilakukan untuk menentukan perbedaan antara non-protein nitrogen dan total nitrogen protein, yang secara luas digunakan pada bidang ilmu pangan dan teknologi.

Walker et al. (2007) menyatakan gonad bulu babi terdiri atas 2 bagian yakni sel-sel germinal(sel-sel reproduksi) dan sel-sel nutrisi. Protein, lemak, dan karbohidrat (glikogen) merupakan bagian dari sel-sel nutrisi gonad bulu babi. Dalam proses pematangan gonad, protein, lemak, dan karbohidrat (glikogen) ini akan mengalami penurunan sedangkan kadar air akan mengalami peningkatan. Karena ketiga zat gizi ini yang dipakai selama proses pematangan gonad. Setelah proses pematangan gonad ini, maka gonad siap untuk melakukan proses pemijahan. Gonad yang telah matang atau dewasa akan ditandai dengan volume gonad yang memenuhi bagian dalam cangkang dan ukurannya yang berkisar antara $80-100 \mu \mathrm{m}$.

Kandungan air gonad bulu babi dalam penelitian lebih rendah yakni $64,9 \%$ dibandingkan hasil penelitian Zlatanos et al. (2009) dalam gonad bulu babi merupakan salah satu komponen utama penyusun bulu babi. Isengard (2001) menyatakan bahwa stabilitas dan masa simpan suatu bahan sangat ditentukan oleh kandungan air di dalamnya. Tingginya kadar air dapat menyebabkan bahan pangan mudah mengalami kemunduran mutu salah satunya 
akibat aktivitas mikroorganisme, sehingga diperlukan penanganan yang cepat dan tepat dengan mempertahankan rantai dingin.

Kadar abu merupakan akumulasi dari semua jenis mineral dan komponen anorganik yang ada pada suatu bahan pangan salah satunya adalah bulu babi. Kadar abu sampel tidak berbeda jauh dibandingkan dengan Zlatanos et al. (2009) yakni 2,72\%. Kadar abu dari masing-masing spesies berbeda-beda, tergantung dari lokasi, ketersediaan mineral pada daerah tumbuh bulu babi. Walaupun diperlukan dalam jumlah sedikit, mineral juga diperlukan untuk proses metabolisme dan pertumbuhan (Hammer et al. 2006).

Darsono (1986) menyatakan gonad bulu babi berkualitas baik memiliki tekstur kompak dan padat, namun pada saat telah mencapai fase matang (dewasa) tekstur gonad lebih lunak dan berlendir ini diduga disebabkan karena tingginya kadar air pada gonad. Fase yang tepat untuk proses pemanenan bulu babi juga sangat mempengaruhi proses keberlanjutan bulu babi itu sendiri. Fase yang tepat untuk proses pemanenan bulu babi ini pada saat fase pijah lanjut (post spawning/ recovery) dan pada fase ini juga tekstur gonad bulu babi kompak dan padat sehingga dapat dimanfaatkan sebagai bahan makanan bergizi. Kualitas bulu babi tidak bergantung pada perkembangan proses gametogenesisnya tetapi tergantung dari akumulasi nutrien pada gonad bulu babi tersebut.

\section{Ekstrak Gonad Bulu Babi}

Proses ekstraksi gonad bulu babi dilakukan dengan metode maserasi bertingkat. Senyawa bioaktif yang berikatan dengan bahan akan ditarik oleh pelarut berdasarkan tingkat kepolaran. Pelarut yang digunakan adalah n-heksan (non polar), etil asetat (semi polar), dan metanol (polar). Warna ketiga esktrak berbeda, untuk ekstrak n-heksan berwarna coklat keemasan dan agak cair. Ekstrak etil asetat berwarna coklat kehitaman dan berbentuk pasta sedangkan untuk pelarut metanol berwarna coklat kekuningan.
Ekstraksi dengan menggunakan pelarut yang berbeda menghasilkan ekstrak dengan bobot yang berbeda, yakni ekstrak etil asetat dengan persentasi tertinggi $16,25 \%$, ekstrak metanol 4,31\%, dan ekstrak n-heksan 1,72\%. Bahan kimia pelarut memiliki kemampuan yang berbeda-beda untuk mengekstrak komponen bioaktif tertentu dari suatu bahan. Tingginya rendemen pada ekstrak etil asetat berkaitan dengan senyawa semi polar dalam gonad bulu babi yang larut dalam pelarut etil asetat. Rahayu (1999) menyatakan bahwa pelarut semi polar mampu melarutkan senyawa-senyawa yang berasal dari golongan alkaloid, dan aglikon (alkoholik, fenolik, steroid, flavonoid, dan saponin), sedangkan pelarut n-heksana menghasilkan rendemen lebih rendah dibandingkan kedua pelarut lainnya, ini diduga karena gonad bulu babi mengandung sedikit senyawa non-polar. Hougthon dan Raman (1998) menyatakan bahwa pelarut non polar mampu melarutkan senyawa yang berasal dari golongan trigliserida, minyak atsiri, dan asam lemak.

\section{Komponen Bioaktif Gonad Bulu Babi}

Analisis komponen bioaktif dilakukan dengan metode fitokimia (Tabel 3). Metode ini digunakan untuk mengetahui kandungan metabolit sekunder dari suatu bahan. Pengujian dilakukan terhadap ekstrak metanol, ekstrak etil asetat, dan ekstrak n-heksan gonad bulu babi. $\mathrm{H}$

Hasil yang diperoleh menunjukkan bahwa ketiga jenis ekstrak mengandung senyawa bioaktif dari golongan steroid, triterpenoid, dan saponin. Penelitian yang dilakukan oleh Septiadi et al. (2013) dengan menggunakan sampel dari filum echinodermata (teripang) memperoleh hasil yang sesuai dengan penelitian ini yakni ekstrak teripang mengandung komponen bioaktif triterpenoid, steroid, dan saponin pada ekstrak etil asetat dan metanol, dan tidak terdeteksi pada ekstrak n-heksana.

Saponin (steroid oligoglycosides) bersifat larut dalam air dan etanol dan tidak larut 
Tabel 3 Hasil analisis komponen bioaktif gonad bulu babi

\begin{tabular}{lccc}
\hline \multirow{2}{*}{ Bagian bulu babi } & \multicolumn{3}{c}{ Pelarut } \\
\cline { 2 - 4 } & n-heksana & Etil asetat & Metanol \\
\hline Alkaloid & - & - & + \\
Flavonoid & + & + & - \\
Fenol-hidrokuinon & - & + & - \\
Steroid & + & + & + \\
Triterpenoid & + & + & + \\
Tanin & - & - & - \\
Saponin & + & + & + \\
\hline Keterangan: $(-)=$ tidak terdeteksi, $(+)=$ terdeteksi
\end{tabular}

dalam eter. Saponin juga memiliki peran dalam antibakteri dengan mekanisme kerjanya mengganggu permeabilitas membran sel bakteri, sehingga terjadi bakterilisis pada sel bakteri yang ditandai dengan pecahnya membran sel (Pranoto et al. 2012). Saponin terdapat pada tumbuhan terestrial namun pada binatang saponin secara eksklusif terdapat pada echinodermata. Fungsi biologi saponin pada echinodermata berhubungan dengan sistem pertahanan diri terhadap fungi laut, predator, dan parasit. Senyawa ini juga berperan dalam proses reproduksi untuk jenis lain dari echinodermata yakni bintang laut dan teripang (Stonik dan Elyakov 1988).

Steroid dan triterpenoid merupakan salah satu komponen dari golongan terpenoid. Senyawa bioaktif yang berasal dari golongan steroid dan triterpenoid juga memiliki potensi sebagai antibakteri. Pertumbuhan bakteri akan dihambat dengan cara penghambatan sintesis protein dan menyebabkan perubahan komponen-komponen penyusun sel bakteri itu sendiri. Rosyidah et al. (2010) menyatakan bahwa terpenoid mudah larut dalam lipid, sifat inilah yang menyebabkan komponen ini lebih mudah menembus dinding sel bakteri.

\section{Toksisitas Ekstrak Gonad}

Hasil analisis toksisitas BSLT menunjukkan bahwa nilai $\mathrm{LC}_{50}$ masingmasing ekstrak sebagai berikut, ekstrak n-heksana 471,861 ppm, ekstrak etil asetat 563,226 ppm, dan ekstrak metanol 577,531 ppm. Hasil ini lebih tinggi dibandingkan dengan Bragadeeswaran et al. (2013), yakni nilai $\mathrm{LC}_{50}$ ekstrak air Temnopleurus toreumaticus sebesar $0,12 \mathrm{mg} / \mathrm{mL}(120 \mu \mathrm{g} /$ $\mathrm{mL}$ ), hasil ini menunjukkan bahwa ekstrak air T. toreumaticus lebih aktif dibandingkan dengan ekstrak gonad D. setosum. Perbedaan hasil ini karena perbedaan pelarut yang digunakan. Albuntana et al. (2011) menyatakan bahwa fraksi air bersifat sangat aktif terhadap BSLT karena sifatnya yang sangat polar, sehingga senyawa aktif $T$. toreumaticus lebih banyak terkonsentrasi pada pelarut air.

Toksisitas dari suatu senyawa sangat menentukan penggunaannya dalam aplikasi bidang obat-obatan yakni penentuan dosis. Déciga-Campos et al. (2007) menyatakan bahwa kriteria toksisitas berdasarkan nilai $\mathrm{LC}_{50}$ terdiri atas 3 yakni $\mathrm{LC}_{50}>1000 \mu \mathrm{g} / \mathrm{mL}$ (non toksik), $\geq 500 \leq 1000 \mu \mathrm{g} / \mathrm{mL}$ (toksisitas lemah) dan $<500 \mu \mathrm{g} / \mathrm{mL}$ (toksik).

Firdayani (2003) menyatakan bahwa suatu ekstrak yang bersifat toksik yakni nilai $\mathrm{LC}_{50}<1000$ ppm maka dapat dikembangkan ke arah pengembangan obat alternatif antikanker untuk mengisolasi senyawa sitotoksiknya, sedangkan ekstrak tidak bersifat toksik apabila nilai $\mathrm{LC}_{50}>1000 \mathrm{ppm}$, maka penelitian dapat dilanjutkan dengan melihat potensi lain dari ekstrak tersebut dengan menggunakan hewan uji seperti tikus atau mencit. 


\section{Aktivitas Antibakteri Ekstrak Gonad Bulu Babi}

Zona hambat yang terbentuk menunjukkan adanya aktivitas ekstrak untuk menghambat pertumbuhan bakteri. Pengamatan dilakukan tiap 2 jam selama 24 jam, tujuannya untuk melihat sifat dari bakteri uji. Hasil yang ditampilkan pada Gambar 2 merupakan pengamatan jam ke-6 sampai jam ke-12.

Hasil menunjukkan bahwa diameter zona hambat tertinggi terdapat pada ekstrak etil asetat yakni $4,13 \mathrm{~mm}$ terhadap bakteri E. coli dan $2,71 \mathrm{~mm}$ terhadap bakteri S. aureus pada konsentrasi 2 mg dibandingkan dengan ekstrak n-heksana dan metanol. Hasil yang diperoleh juga menunjukkan bahwa ekstrak gonad bulu babi bersifat bakteristatik terhadap bakteri uji, karena zona hambat terbentuk hanya pada jam ke-6 sampai jam ke- 12 .

Penelitian antibakteri pada bulu babi telah dilakukan, beberapa diantaranya yakni Shamsudin et al. (2010) yang menyatakan bahwa ekstrak etanol bulu babi $D$. savignyi menujukkan aktivitas antibakteri terbaik dibandingkan dengan pelarut metanol dan buffer fosfat yakni $12 \mathrm{~mm}$ terhadap bakteri S. aureus, sedangkan Uma dan Parvathavarthini (2010) menyatakan bahwa ekstrak n-heksan bulu babi Temnopleurus alexandri menunjukkan aktivitas antibakteri tertinggi pada bakteri
Bacillus subtilis dan Pseudomonas aeruginosa dengan diameter zona hambat secara berurutan $16 \mathrm{~mm}$ dan $15 \mathrm{~mm}$ pada konsentrasi 5000 ppm. Hasil ini menunjukkan bahwa bulu babi memiliki kemampuan sebagai antibakteri terhadap berbagai jenis bakteri.

Aktivitas antibakteri dalam suatu bahan dipengaruhi oleh komponen bioaktif yang ada di dalamnya. Komponen bioaktif yang berperan dalam menghambat aktivitas bakteri umumnya berasal dari golongan saponin, terpenoid, steroid, alkaloid, dan flavonoid dengan mekanisme kerjanya yakni merusak membran sel bakteri (Darsana et al. 2012). Pendapat ini sejalan dengan hasil yang diperoleh yakni senyawa bioaktif yang terdeteksi pada ekstrak gonad bulu babi berasal dari golongan senyawa saponin, steroid, dan triterpenoid. Bulu babi ditemukan juga memiliki aktivitas antimikroba terhadap bakteri, virus, dan fungi yang dikenal dengan antimicrobial peptides (AMPs) yang terdapat pada cairan coelomic dan memiliki berat molekul kecil yakni $<10 \mathrm{kDa}$ serta asam amino tidak lebih dari 100 (Scihillaci dan Arizza 2013).

Zona hambat yang terbentuk diketahui bahwa aktivitas antibakteri ekstrak gonad bulu babi termasuk dalam kategori lemah. Davis dan Stout (1971) menyatakan bahwa terdapat 3 kategori daerah hambatan zat aktif berdasarkan diameter zona hambatnya

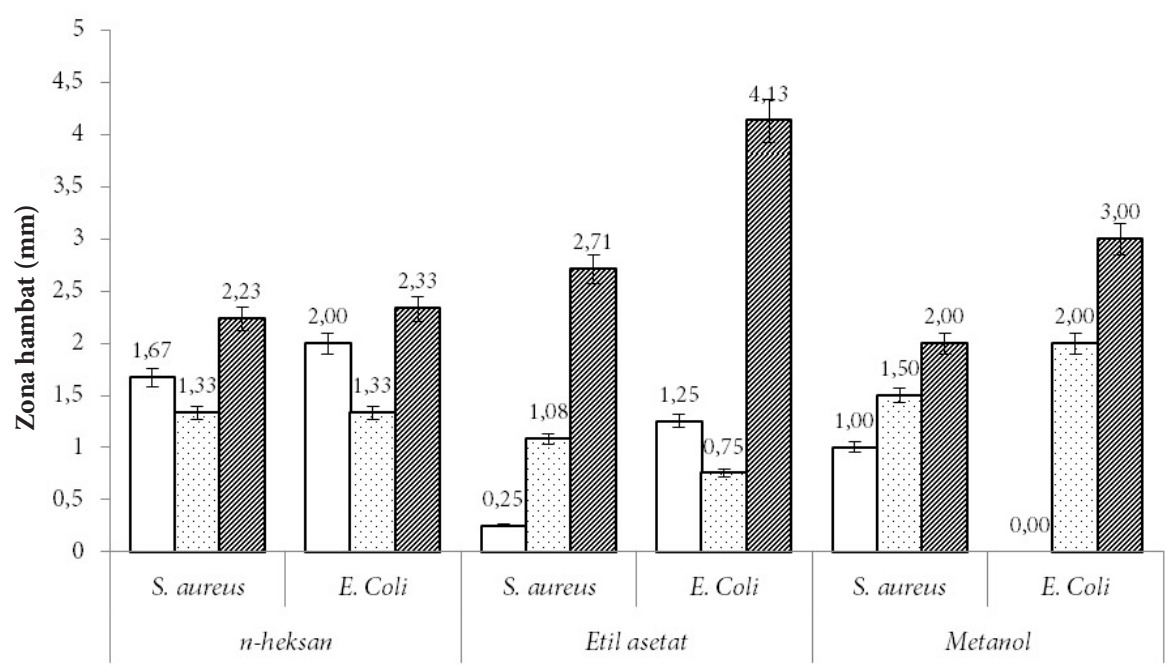

Gambar 2 Aktivitas antibakteri ekstrak gonad bulu babi ( $\square$ ) 0,5 mg, ( ) $1 \mathrm{mg}$, ( $\square) 2 \mathrm{mg}$ 
yakni untuk kategori lemah diameter zona hambatnya $<5 \mathrm{~mm}$, kategori sedang yakni 5-10 mm, dan kategori kuat yakni 10-20 mm.

\section{KESIMPULAN}

Ekstrak gonad bulu babi menunjukkan aktivitas antibakteri tertinggi dengan zona hambat $1,83 \pm 0,74 \mathrm{~mm}$ terhadap bakteri E. coli dan $1,5 \mathrm{~mm}$ terhadap bakteri S. aureus pada konsentrasi $2 \mathrm{mg}$. maka gonad bulu babi yang digunakan sebagai sampel pada penelitian utama. Komposisi kimia gonad bulu babi adalah kadar air $(64,97 \pm 0,08 \%)$, kadar abu (2,72 $\pm 0,13 \%)$, kadar lemak (19,73 $\pm 0,04 \%)$, kadar protein $(12,26 \pm 0,3 \%)$, dan kadar karbohidrat $(0,33 \pm 0,17 \%)$. Komponen bioaktif yang terdeteksi pada gonad bulu babi adalah steroid, triterpenoid, dan saponin. Nilai $\mathrm{LC}_{50}$ ekstrak gonad bulu babi yaitu ekstrak n-heksana 471,861 ppm, ekstrak etil asetat 563,226 ppm, dan metanol 577,531 ppm. Uji aktivitas antibakteri ekstrak gonad bulu babi tertinggi pada ekstrak etil asetat dengan diameter zona hambat $2,71 \mathrm{~mm}$ terhadap bakteri $S$. aureus dan $4,13 \mathrm{~mm}$ terhadap bakteri E. coli.

\section{DAFTAR PUSTAKA}

[AOAC]. 2005. Association of Official Analytical Chemist. Official Method of Analysis of The Association of Official Analytical of Chemist. Arlington (US). Published by The Association of Official Analytical Chemist. Inc.

Abubakar L, Wangi C, Uku J, Ndirangu S. 2012. Antimicrobial activity of various extracts of the sea urchin Tripneustes gratilla (Echinoidea). African Journal of Pharmacology and Therapeutics 1(1):1923.

Albuntana A, Yasman, Wardhana W. 2011. Uji toksisitas ekstrak empat jenis teripang suku Holothuriide dari Pulau Penjaliran Timur Kepulauan Seribu, Jakarta menggunakan brine shrimp lethality test (BSLT). Jurnal Ilmu dan Teknologi Tropis 3(1):65-72.

Aminur RM, Arshad A, Yusoff FM. 2014. Sea urchins (echinodermata: Echinoidea): their biology, culture and bioactive compounds. International Conference on Agricultural, Ecological and Medical Sciences 39-48. doi:10.15242/iicbe.c714075.

Andersson L, Bohlin L, Iorizzi M, Riccio R, Minale L, Moreno-Lopez W. 1989. Biological activity of some saponins and saponin-like compounds from starfish and brittle-stars. Toxicon 27(2):179-188.

Aprilia HA, Pringgenies D, Yudiati E. 2012. Uji toksisitas ekstrak kloroform cangkang dan duri landak laut (Diadema setosum) terhadap mortalitas Nauplius artemia sp. Journal of Marine Research 1(1):75-83.

Arias-Forero D, Hayashida G, Aranda M, Araya S, Portilla T, García A, Díaz-Palma P. 2013. Protocol for maximizing the triglycerides-enriched lipids production from Dunaliella salina SA32007 biomass, isolated from the Salar de Atacama (Northern Chile). Advances in Bioscience and Biotechnology 04(08):830-839. doi:10.4236/abb.2013.48110.

Aziz A. 1987. Makanan dan cara makan berbagai jenis bulu babi. Journal of Oseana 29(4):91-100

Aziz A. 1993. Beberapa catatan tentang perikanan bulu babi. Journal of Oseana 18(2):65-75.

Beauregard KA, Truong NT, Zhang HY, Lin WY, Beck G. 2001. The detection and isolation of a novel antimicrobial peptide from the echinoderm, Cucumaria frondosa. Advances in Experimental Medicine and Biology 484: 55-62.

Bragadeeswaran S, Kumaran SN, Sankar PP, Prabahar R. 2013. Bioactive potential of sea urchin Temnopleurus toreumaticus from Devanampattinam, Southeast coast of India. Journal of Pharmacy and Alternative Medicine 2(3): 9-18.

Bryana PJ, McClintock JB, Hopkins TS. 1997. Structural and chemical defenses of echinoderms from the northern Gulf of Mexico. Journal of Experimental Marine Biology and Ecology 210(2):173-186. 
Byrne M, Sewell MA, Prowse TAA. 2008. Nutritional ecology of sea urchin larvae: influence of endogenous and exogenous nutrition on echinopluteal growth and phenotypic plasticity in Tripneustes gratilla. Functional Ecology 22(4):643-648.

Canicatti C, Roch P. 1989. Studies on Holothuria polii (Echinodermata) antibacterial proteins. I. Evidence for and activity of a coelomocyte lysozyme. Experientia 45(8):756-759.

Dahl WJ, Jebson P, Louis DS. 2010. Sea urchin injuries to the hand: A case report and review of the literature. The Iowa Orthopaedic Journal 30:153-156.

Darsana IGO, Besung INK, Mahatmi H. 2012. Potensi daun binahong (Anredera cordifolia (Tenore) Steenis) dalam menghambat pertumbuhan bakteri Escherichia Coli secara In vitro. Indonesia Medicus Veterinus 1(3):337-351.

Darsono P. 1986. Gonad bulu babi. Oseana 11(4):151-162.

Davis WW, Stout T R. 1971. Disc plate method of microbiological antibiotic assay. II. Novel procedure offering improved accuracy. Applied Microbiology 22(4):666670.

Déciga-Campos M, Rivero-Cruz I, ArriagaAlba M, Castaneda-Corral G, AngelesLopez GE, Navarrete A, Mata R. 2007. Acute toxicity and mutagenic activity of Mexican plants used in traditional medicine. Journal of Ethnopharmacology 110(2):334342. doi:10.1016/j.jep.2006.10.001.

Dincer T, Cakli S. 2007. Chemical composition and biometrical measurements of the Turkish sea urchin (Paracentrotus lividus, Lamarck, 1816). Critical Reviews in Food Science and Nutrition 47(1):21-26. doi:10.1080/10408390600550265.

Facchini PJ. 2001. Alkaloid biosynthesis in plants: Biochemistry, cell biology, molecular regulation, and metabolic engineering applications. Annual Review of Plant Biology 52(1):29-66.

Firdayani, Agustini K, Kusumaningrum S.
2003. Uji sitotoksisitas ekstrak methanol spons Gelliodes fibulatus terhadap A. salina. Jurnal Farmasi Indonesia 1(3):141-145.

Hammer H, Hammer B, Watts S, Lawrence A, Lawrence J. 2006. The effect of dietary protein and carbohydrate concentration on the biochemical composition and gametogenic condition of the sea urchin Lytechinus variegatus. Journal of Experimental Marine Biology and Ecology 334(1):109-121. doi:10.1016/j. jembe.2006.01.015.

Harborne JB. 1984. Phytochemical Methods: A guide to modern technique of plant analysis. ( $2^{\text {nd }}$ edition). Chapman and Hall. London. 19:137-168.

Haug T Kjuul AK, Styrvold OB, Sandsdalen E, Olsen ØM, Stensvåga K. 2002. Antibacterial activity in Strongylocentrotus droebachiensis (Echinoidea), Cucumaria frondosa (Holothuroidea), and Asterias rubens (Asteroidea). Journal of Invertebrate Pathology 81(2):94-102.

Heim KE, Tagliaferro AR, Bobilya DJ. 2002. Flavonoid antioksidan chemistry : Metabolism, and structure activity relationships. Journal of Nutritional Biochemistry 13(10):572-584.

Isengard HD. 2001. Water content, one of the most important properties of food. Food Control 12(7):395-400.

Iorizzi M, Bryan P, McClintock J, Minale L, Palagiano E, Maurelli S, Riccio R and Zollo F. 1995. Chemical and biological investigation of the polar constituents of the starfish Luidia clathrata, collected in the Gulf of Mexico. Journal of Natural Product 58(5):653-671.

Jablonski D, Lutz AR. 1983. Larval ecology of marine benthic invertebrates: Paleobiological implications. Journal of Biology Evolutionary 58(1):21-89

Kamizake NKK, Gonçalves MM, Zaia CTBV, Zaia DAM. 2003. Determination of total protein in cow milk powder samples: a comparative study between the Kjeldahl 
method and spectrophotometric methods. Journal of Food Composition and Analysis 16(4):507-516

Kenneth L, Rinehart J, Shaw PD, Shield LS, Gloer JB, Harbour GC, Koker MES, Samain D, Schwartz RE, Tymiak AA, et al. 1981. Marine natural products as sources of antiviral, antimicrobial and antineoplastic agents. Pure and Appi. Chern 53(4):795817.

Leonard LA, Strandberg JD, Winkelstein JA. 1990. Complement-like activity in the sea star Asterias forbesi. Developmental and Comparative Immunology 14(1): 19-30.

Li C, Haug T, Stensvåg K. 2010. Antimicrobial peptides in echinoderms. Invertebrate Survival Journal 7:132-140.

Mayer BN, Ferrigni NR, Putnam JE, Jacobsen LB, Nichols DE, McLauchlin JL. 1982. Brine shrimp: a convenient general bioassay for active plant constituents. Journal of Medical Plants Research 45:3134.

McAlister JS, Moran AL. 2012. Relationships among Egg Size, Composition, and Energy: a comparative study of geminate sea urchins. Journal of Pone 7(7):1-9

Middleton JE, Kandaswami C, Theoharides TC. 2000. The effects of plant flavonoids on mammalian cells: Implications for inflammation, heart disease, and cancer. The American Society for Pharmacology and Experimental Therapeutics 52(4):673751.

Moorthy K, Srinivasan K, Subramanian C, Mohanasundari C, Palaniswamy M. 2007. Phytochemical screening and antibacterial evaluation of stem bark of Mallotus philippinensis var. Tomentosus. African Journal of Biotechnology 6(3):1521-1523.

Pranoto EN, Ma’ruf WF, Pringgenies D. 2012. Kajian aktivitas bioaktif ekstrak teripang pasir (Holothuria scabra) terhadap jamur Candida albicans. Jurnal Perikanan 1(2):18.

Rahayu WP. 1999. Kajian aktivitas antimikroba ekstrak dan fraksi rimpang lengkuas
(Alpinia galanga L. Swartz) terhadap mikroba patogen perusak pangan [disertasi]. Bogor: Institut Pertanian Bogor.

Ratna DF. 2002. Pengaruh penambahan gula dan lama fermentasi terhadap mutu pasta gonad bulu babi Diadema setosum dengan Lactobacillus plantarum sebagai kultur starter. [skripsi]. Bogor: Institut Pertanian Bogor.

Rosyidah K, Nurmuhaimina SA, Komari N, Astuti MD. 2010. Aktivitas antibakteri fraksi saponin dari kulit batang tumbuhan kasturi (Mangifera casturi). Alchemy 1(2):53-103.

Schillaci D, Arizza V. 2013. Echinoderm antimicrobial peptides to contrast human pathogens. Natural Product Chemistry and Research 1(2):1-4

Septiadi T, Pringgenies D, Radjasa OK. 2013. Uji fitokimia dan aktivitas antijamur ekstrak teripang keling (Holoturia atra) dari pantai Bandengan Jepara terhadap jamur Candida albicans. Journal of Marine Research 2(2):76-84

ServiceM, Wardlaw AC. 1984. Echinochrome-A as a bactericidal substance in the coelomic fluid of Echinus esculentus (L.). Comp. Biochem. Physiol B(79): 161-165.

Shamsuddin AA, Hakim MD, Kumari GM, Noraznawati. 2010. Antibacterial activity of threee species of sea urchin extracts from Pulau Bidong, Terengganu. Journal of Sustainability Science and Management 5(1):116-124

Stabili L, Pagliara P 1994. Antibacterial protection in Marthasterias glacialis eggs characterization of lysozyme-like activity. Comparative Biochemistry $\mathrm{B}(109): 709$ 713.

Stonik VA, Elyakov GB. 1988. Secondary metabolites from echinoderms as chemotaxonomic markers Di dalam: Scheuer PJ (editor) Bioorganic Marine Chemistry. Honolulu, Hawai, Springer.

Suwignyo S, Widigdo B, Wardiatno Y, Krisanti M. 2005. Avertebrata Air. Depok: Penebar 
Swadaya

Tuwo A. 1995. Aspek biologi bulu babi jenis

Tripneustes gratilla di Pulau Kapoposan, Dati II Pangkep, Sulawesi Selatan. Oseana 20(1):21-29.

Uma B, Parvathavarthini R. 2010. Antibacterial effect of hexane extract of sea urchin, Temnopleurus alexandri (Bell, 1884). International Journal of PharmTech Research 2(3):1677-1680.

Vimono IB. 2007. Sekilas mengenai landak laut. Oseana 32(3):37-46.

Walker CW, Unuma T, Lessera MP. 2007. Edible sea urchin: Biology and ecology. Florida, USA: Elsevier
Wang L, Weller CL. 2006. Recent advances in extraction of nutraceuticals from plants. Trend in Food Science and Technology 17:300-312

Zakaria IJ. 2013. Komunitas bulu babi (Echonoidea) di Pulau Cingkuak, Pulau Sikuai dan Pulau Setan Sumatera Barat. Prosiding SEMIRATA. Universitas Lampung 10-12 Mei 2013. 1(1)381-387.

Zlatanos S, Laskaridis K, Sagredos A. 2009. Determination of proximate composition, fatty acid content and amino acid profile of five lesser-common sea organisms from the Mediterranean Sea. International Journal of Food Science and Technology 44(8):15901594.doi:10.1111/j.1365-2621.2008.01870. 